\title{
BMJ Open Quality Patient-centred improvement to repeat prescribing using the Always Event concept
}

\author{
Katherine Anne Grosset, ${ }^{1}$ Elaine Deary, ${ }^{1}$ Nancy El-Farargy ${ }^{2}$
}

To cite: Grosset KA, Deary E, El-Farargy N. Patient-centred improvement to repeat prescribing using the Always Event concept.BMJ Open Quality 2017;6:e00042. doi:10.1136/ bmjoq-2017-000042

- Additional material is published online only. To view please visit the journal online (http://dx.doi.org/10.1136/ bmjoq-2017-000042)

Received 5 March 2017 Revised 20 October 2017 Accepted 1 November 2017

\section{CrossMark}

${ }^{1}$ The Cairns Practice, Shettleston Health Centre, Glasgow, UK ${ }^{2}$ NHS Education for Scotland, Edinburgh, UK

Correspondence to Dr Katherine Anne Grosset; kgrosset@nhs.net

\section{ABSTRACT}

Repeat prescriptions are prescriptions issued to a patient for a second or subsequent time without requiring a consultation with a doctor. Repeat prescribing is common and an efficient system is necessary to deliver a highquality service. Always Events can be used to drive patient-centred improvements in healthcare delivery. Our aim was to use the Always Event concept to improve our repeat prescribing system. This quality improvement project was carried out in a deprived, inner-city general practice setting in Glasgow, UK. 51 patients taking repeat medications completed short questionnaires, and the Always Event 'Repeat prescriptions should be ready and available to collect' was generated. We used the Plan-DoStudy-Act cycles to elucidate how our system could be improved and check if our intervention was effective. Over a 3-day period in July 2016, 269 out of 292 prescriptions $(92.1 \%)$ were ready. We mapped out the repeat prescribing process and discovered that sometimes reception staff graded a request as inappropriate, for example, requested too early, and these requests were therefore not processed. Patients would then attend to collect a prescription that was not there. This was both inconvenient for the patient and time-consuming for the reception staff to investigate the reason. Our system was changed so that any request that was not being processed was recorded and the patient informed. In September 260 out of 267 (97.4\%) prescriptions were ready, in November 350 out of 364 (96.2\%), and in February 2017314 out of 323 (97.2\%) were ready. In conclusion, the Always Event approach allowed us to elicit important feedback from patients to identify a weakness in our repeat prescribing system, which was simple to rectify and led to an improved, more efficient service.

\section{PROBLEM}

Repeat prescriptions are issued to a patient for a second or subsequent time without requiring a consultation with a doctor. In the past 20 years, the number of repeat prescription items issued has doubled from 5.8 to 13.3 items per patient per annum, ${ }^{1}$ and this impacts significantly on National Health Service (NHS) costs, related clinical risks, increased workloads, organisation of work in general practice and patients' experience of healthcare provision. ${ }^{2} 3$ In our practice, anecdotally a significant proportion of repeat prescriptions are not ready for collection when patients attend to collect their prescriptions. If prescriptions are not ready for collection, this can be time-consuming and frustrating for patients and staff.

\section{BACKGROUND}

The repeat prescription process is complex and involves doctors deciding which items can be requested by patients without a consultation between clinician and patient. ${ }^{4}$ The medication will usually have been initially prescribed by a medical practitioner at consultation, and procedures are in place to monitor the safety, compliance and necessity of repeat prescriptions. Repeat prescribing accounts for up to three-quarters of all drugs prescribed and four-fifths of drug costs in UK general practice; around half of all registered patients receive treatment by repeat prescription, and rates are rising. ${ }^{3}$ This quality improvement project took place within an inner-city general practice in Glasgow, UK, with a practice population of just over 9000 patients. The practice is one of the 'Deep End Practices', namely one of the 100 general practices that serve the most severely deprived populations in Scotland. ${ }^{56}$ We have a higher proportion than average of elderly patients compared with other practices in our area, with $15 \%$ of the practice population aged over 65 . We train and teach both postgraduate doctors and undergraduate medical students.

The practice has a repeat prescribing system in place, and written information is given to patients via the practice leaflet and the practice website. ${ }^{7}$ Additionally when a repeat item is issued, there is a written record given to the patient regarding which items are on repeat and how to request repeat medication. Patients are advised that repeat prescriptions will be available for collection 48 working hours after making the request.

We have worked at improving our repeat prescribing systems over the years, including following the NHS Scotland and NHS 
Institute for Innovation productive general practice module on prescribing. ${ }^{8}$

Our practice processes over 100 repeat prescriptions per day, most of these are 'on repeat' on our computer system, and there are protocols in place so that requests can be processed by reception staff. There are also 'special requests' that are looked at individually and processed by the doctors. There is a separate system for urgent requests, which are processed on the day and can be collected after 16:00. The General Medical Council provided guidelines on good practice in prescribing. ${ }^{910}$

Traditional methods to optimise quality of healthcare delivery such as patient experience and satisfaction surveys have limitations in that they tend not to focus on a specific area, making it more difficult to act on patient feedback to drive improvements. There is growing interest in the Always Events (AE) concept as a method to drive patient-centred improvements in healthcare delivery. The AE approach directly engages with patients at a local level to gauge what they want to happen when they interact with care services and focuses on a specific area. An AE can be defined as 'a clear, action-oriented and pervasive practice or set of behaviours that, when implemented reliably, will ensure an optimal patient and family experience and improved outcomes' ${ }^{11}$ and can be used to drive patient-centred improvements in healthcare delivery. ${ }^{12}$ Patients are asked to complete a short AE questionnaire, the responses are themed, and these data are used to judge what can become an AE. ${ }^{13}$ The following are the criteria for determining an AE:

- It is any healthcare interaction, process or outcome that is judged by patients, carers or relatives to be a highly important determinant of care quality and experience.

- It is unambiguous and specific to enable reliable measurement.

- It is consistently deliverable to applicable patient groups by all relevant healthcare organisations, teams and individuals.

- It is feasible as part of routine healthcare delivery.

Our aim was to use the $\mathrm{AE}$ process to drive patient-centred quality improvement in our repeat prescribing system (see online supplementary file).

\section{MEASUREMENT}

The first step was to use the $\mathrm{AE}$ process to identify where patients felt improvement was needed in our repeat prescribing process (see online supplementary appendix A). We then planned to use the Plan-DoStudy-Act (PDSA) approach to implement change. The PDSA is a four-step sequential improvement tool. ${ }^{14}$ This approach was used because teams can test multiple, small and incremental changes to everyday work practices and systems, ${ }^{15}$ and small samples can be used to drive change to improve systems that are used on a daily

\begin{tabular}{|c|c|c|c|c|c|}
\hline Cycle & Plan/Predication & Do & Study & Act & Timeline \\
\hline 1 & $\begin{array}{l}\text { A percentage of repeat } \\
\text { prescriptions are not available } \\
\text { for collection. }\end{array}$ & $\begin{array}{l}\text { Point prevalence } \\
\text { of percentage of } \\
\text { prescriptions available } \\
\text { for collection }\end{array}$ & $\begin{array}{l}269 / 292(92.1 \%) \text { repeat } \\
\text { prescriptions were } \\
\text { available for collection. }\end{array}$ & $\begin{array}{l}\text { Mapped out repeat } \\
\text { prescription process }\end{array}$ & July 2016 \\
\hline 2 & $\begin{array}{l}\text { Percentage not available for } \\
\text { collection will be reduced by } \\
\text { proactively advising patients } \\
\text { that their prescription had not } \\
\text { been processed. }\end{array}$ & $\begin{array}{l}\text { Repeat point } \\
\text { prevalence of } \\
\text { percentage of } \\
\text { prescriptions available } \\
\text { for collection }\end{array}$ & $\begin{array}{l}260 / 267(97.4 \%) \text { repeat } \\
\text { prescriptions were } \\
\text { available for collection. }\end{array}$ & $\begin{array}{l}\text { Reduced the } \\
\text { number of } \\
\text { prescriptions not } \\
\text { available } \\
\text { Repeat the } \\
\text { process to check } \\
\text { sustainability }\end{array}$ & September 2016 \\
\hline 3 & $\begin{array}{l}\text { Percentage of prescriptions } \\
\text { not available for collection will } \\
\text { remain low if the process of } \\
\text { proactively advising patients } \\
\text { (that prescriptions have not } \\
\text { been processed) has been } \\
\text { sustained. }\end{array}$ & $\begin{array}{l}\text { Repeat point } \\
\text { prevalence of } \\
\text { percentage of } \\
\text { prescriptions available } \\
\text { for collection }\end{array}$ & $\begin{array}{l}350 / 364(96.2 \%) \text { repeat } \\
\text { prescriptions were } \\
\text { available for collection. }\end{array}$ & $\begin{array}{l}\text { Improvement has } \\
\text { been sustained and } \\
\text { will be checked } \\
\text { periodically. }\end{array}$ & November 2016 \\
\hline 4 & $\begin{array}{l}\text { Percentage not available for } \\
\text { collection will remain low as } \\
\text { staff have found increased } \\
\text { efficiency and reception area } \\
\text { runs more smoothly. }\end{array}$ & $\begin{array}{l}\text { Repeat point } \\
\text { prevalence of } \\
\text { percentage of } \\
\text { prescriptions available } \\
\text { for collection }\end{array}$ & $\begin{array}{l}314 / 323(97.2 \%) \text { repeat } \\
\text { prescriptions were } \\
\text { available for collection. }\end{array}$ & $\begin{array}{l}\text { Improvement } \\
\text { remains sustained. } \\
\text { Incidents of repeat } \\
\text { prescriptions } \\
\text { are not available } \\
\text { to be discussed } \\
\text { at weekly staff } \\
\text { meeting. }\end{array}$ & February 2017 \\
\hline
\end{tabular}




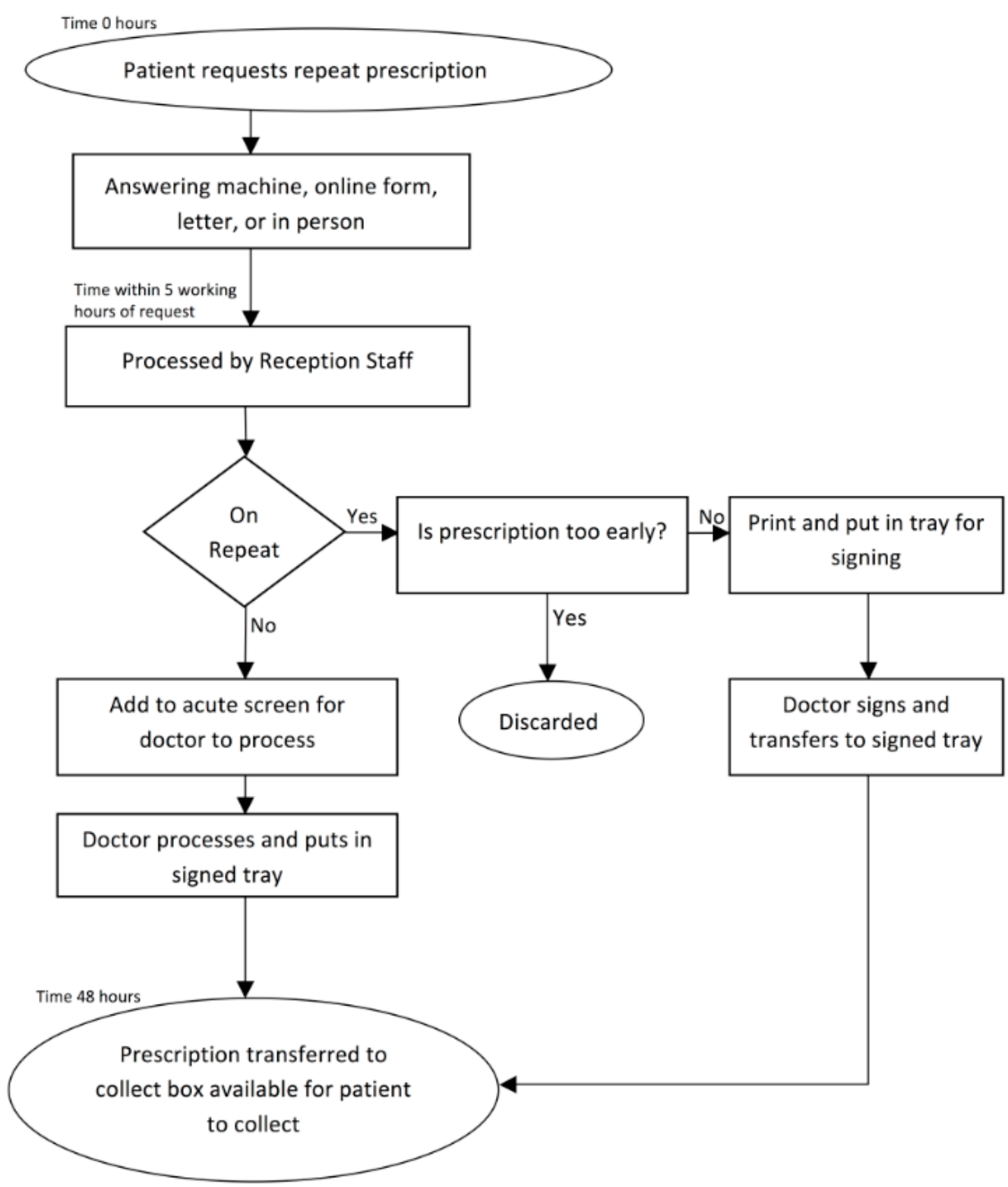

Figure 1 Repeat prescribing flow map from patients putting in a repeat prescription request to collection of the repeat prescription.

basis. ${ }^{16}$ We planned to repeat the PDSA for four cycles on a 2 monthly basis.

\section{BASELINE MEASUREMENT}

Always questionnaires were completed by 51 patients collecting repeat prescriptions in June 2016. Each patient was asked for three responses to the question "what should always happen when you collect a repeat prescription?' There were 89 responses as many patients only gave one or two responses. Patient responses were entered into an Excel spreadsheet and analysed to identify themes. The most prevalent theme identified was that the prescription should be ready when the patient attended to collect it $(n=32)$, followed by the staff should be courteous $(n=14)$, the items should be correct and prescription should be for all items requested $(n=11)$, the person collecting the prescription should have their identity checked $(n=10)$, patient should be told about side effects $(n=4)$, there should be privacy when asked personal details $(n=3)$, and there were 15 other/miscellaneous responses.

We identified our candidate $\mathrm{AE}$ as 'the prescription is ready and available to collect'.

We used this information in cycle 1 of PDSA. The results of the $\mathrm{AE}$ questionnaire were discussed at a staff meeting, and it was decided that we would collect data over 3 days in early July to see how many prescriptions were collected and how many of these were ready and available. Two hundred and ninety-two patients attended to collect repeat prescriptions and 269 (92.1\%) were ready (table 1). 


\section{DESIGN}

After collecting the baseline data, we mapped out the flow from patients putting in a repeat prescription request to collection of the repeat prescription (figure 1). The process is complex and involves many steps. There are multiple possible reasons for prescriptions not being ready and available for collection. It emerged that if a patient requested a prescription too early, namely over a week prior to the prescription being due (requests via the answering machine, online form, letter or in person), the staff had not been recording this and they had just simply not processed the request. Additionally the patient had not been informed that the request was too early. This meant that patients were attending to collect prescriptions that had not been processed, and the staff would then have to investigate what had happened to the request. This process was slow as the issue had not been recorded in patients' records.

\section{STRATEGY}

We hypothesised that if we proactively advised patients that their repeat prescription request was too early, they would not attend to collect a prescription that had not been processed.

Practice staff were instructed to record that requested items were not yet due, inform the patient of this and record that the patient had been informed in the patient records. If the patient was not satisfied, the request was to be passed to a doctor. The change was discussed at a practice meeting so the entire team was aware of the change.

We then repeated the process of recording the proportion of prescriptions that were ready and available to collect.

\section{RESULTS}

Table 1 shows the results of the four PDSA cycles. The 3-day data collection was initially repeated in September 2016; 260 out of 267 (97.4\%) prescriptions were ready and available. Of the prescriptions that were not ready:

- Two had been requested too early by pharmacies.

- One involved a patient who does not speak English and an interpreter was required.

- One had been done 2 days previously but was not in the box for no obvious reason.

- One had spoken to the duty doctor earlier and the script was still in the general practitioner's room.

- One was not clear how or when requested, but the patient came to collect.

- One had been picked up as too early and the staff had tried to contact the patient to inform them, but had been unsuccessful. When the patient attended to collect the prescription, the audit trail was clearly recorded in the patient's record allowing the staff to inform the patient straight away.

The process was repeated again in November 2016, with 350 out of $364(96.2 \%)$ ready. There was a higher volume of repeat prescription requests in November. Of
14 prescriptions, 10 that were not ready and available were requested by pharmacy staff who were collecting prescriptions for other patients, and asked if these additional prescriptions were ready (even though the 48-hour processing time for those prescriptions had not elapsed). In February 2017, 314 out of 323 (97.2\%) were ready. The improvement was sustained.

\section{LESSONS AND LIMITATIONS}

The person-centred element is critical to the AE approach, and this enabled us to respond to patient feedback on what would enhance their experience of the repeat prescription process. The patients highlighted an inefficiency in the repeat prescribing process, and our team were able to use this information to create a more efficient system for all involved in the process by lessening the related workload and reducing frustration all round. We feel the standard now achieved is very good, and staff and patients have commented on how the reception area runs more smoothly. This reinforces the gain of the change and makes it more likely to be sustained. The follow-up data highlighted that pharmacies are repeatedly asking for prescriptions too early, and this is another area that can be addressed. This could be reduced by alternative systems such as a community pharmacist-managed repeat prescription service. ${ }^{17}$ We plan to randomly repeat the process periodically to check that the system continues to function well. The process was feasible in a large, busy practice. A limitation is that it is time-consuming for staff to contact patients, and it may not be possible to contact patients by phone. We have not sent letters to patients if we are unable to contact them by phone, as the timeline is such that they will usually present to the practice before it is practically possible to send a letter. Similar issues are seen in other primary care systems, such as processing and communicating laboratory results. Bowie $e t a l^{18}$ highlighted four themes in this process, namely system variations and weaknesses, doctor to administrator communication, informing patients of test results, and patient follow-up and confidentiality, which are similarly pertinent in the processing of repeat prescription requests.

\section{CONCLUSION}

In conclusion, the AE process identified a weakness in our repeat prescription system, which was simple to rectify and has improved the efficiency of our system.

Acknowledgements We would like to acknowledge the patients who participated and all the Cairns Practice staff for their support of the project, and Paul Watson and Paul Bowie for training in Always Event and for the help and support.

Contributors KAG: project design, data collection, data analysis, manuscript writing and editing. ED: project design, data collection, and manuscript review. NEI-F: manuscript review.

Funding NHS Education for Scotland.

Competing interests None declared.

Ethics approval This was a quality improvement study to improve the practice system for the repeat prescribing process and ethical approval was not necessary. 
Provenance and peer review Not commissioned; externally peer reviewed.

Open Access This is an Open Access article distributed in accordance with the Creative Commons Attribution Non Commercial (CC BY-NC 4.0) license, which permits others to distribute, remix, adapt, build upon this work non-commercially, and license their derivative works on different terms, provided the original work is properly cited and the use is non-commercial. See: http://creativecommons.org/ licenses/by-nc/4.0/

(C) Published by the BMJ Publishing Group Limited. For permission to use (where not already granted under a licence) please go to http://www.bmj.com/company/ products-services/rights-and-licensing/

\section{REFERENCES}

1. Petty DR, Zermansky AG, Alldred DP. The scale of repeat prescribing-time for an update. BMC Health Serv Res 2014;14:76.

2. De Smet PA, Dautzenberg M. Repeat prescribing: scale, problems and quality management in ambulatory care patients. Drugs 2004;64:1779-800.

3. Swinglehurst D, Greenhalgh T, Russell J, et al. Receptionist input to quality and safety in repeat prescribing in UK general practice: ethnographic case study. BMJ 2011;343:d6788.

4. Audit Commission. A prescription for improvement: towards more rational prescribing in general practice: Stationery Office Books, 1994.

5. Watt G. Reflections at the deep end. Br J Gen Pract 2012;62:6-7.

6. Watt G, Brown G, Budd J, et al. General Practitioners at the Deep End: The experience and views of general practitioners working in the most severely deprived areas of Scotland. Occas Pap R Coll Gen Pract 2012:i-40.

7. NHS Scotland. The Cairns practice website. http://www. thecairnspractice.co.uk/ (accessed 27 Jul 2016).
8. NHS Education for Scotland. Quality Improvement Hub: NHS Education for Scotland. http://uat.qihub.scot.nhs.uk/quality-a nd-efficiency/outpatient-primary-and-community- care/productivegeneral-practice.aspx (accessed $27 \mathrm{Jul}$ 2016).

9. General Medical Council. Good practice in prescribing and managing medicines and devices. 2014 http://www.gmcuk.org/Prescribing guidance.pdf 59055247.pdf (accessed 18 Jul 2016).

10. General Medical Council. Good medical practice. Manchester: General Medical Council, 2014. http://www.gmc-uk.org/static/ documents/content/GMP_.pdf (accessed 18 Jul 2016).

11. Institute of Healthcare Improvement. Always events initiative. http://www.ihi.org/engage/Initiatives/PatientFamilyCenteredC are/ Pages/AlwaysEvents.aspx (accessed 5 Jan 2017).

12. Bowie $P, M c N a b D$, Ferguson J, et al. Quality improvement and person-centredness: a participatory mixed methods study to develop the 'always event' concept for primary care. BMJ Open 2015;5:e006667.

13. Saldana J. The Coding Manual for Qualitative Researchers. Thousand Oaks, CA: Sage, 2009

14. Taylor MJ, McNicholas C, Nicolay C, et al. Systematic review of the application of the plan-do-study-act method to improve quality in healthcare. BMJ Qual Saf 2014;23:290-8.

15. Leis JA, Shojania KG. A primer on PDSA: executing plan-dostudy-act cycles in practice, not just in name. BMJ Qual Saf 2017;26:572-7.

16. Etchells E, Ho M, Shojania KG. Value of small sample sizes in rapidcycle quality improvement projects. BMJ Qual Saf 2016;25:202-6.

17. Bond C, Matheson C, Williams S, et al. Repeat prescribing: a role for community pharmacists in controlling and monitoring repeat prescriptions. Br J Gen Pract 2000;50:271-5.

18. Bowie P, Halley L, McKay J. Laboratory test ordering and results management systems: a qualitative study of safety risks identified by administrators in general practice. BMJ Open 2014;4:e004245. 
Correction: Patient-centred improvement to repeat prescribing using the always event concept

Grosset KA, Deary E, El-Farargy N. Patient-centred improvement to repeat prescribing using the always event concept. BMJ Open Qual 2017;6:e000042. doi: 10.1136/ bmjoq-2017-000042.

It has come to our attention that some text is inadvertently missing in the contributions section of this paper. The missing text is as follows: NEl-F: mentoring, contributed to the analysis, text and critical manuscript review.

Open access This is an open access article distributed in accordance with the Creative Commons Attribution Non Commercial (CC BY-NC 4.0) license, which permits others to distribute, remix, adapt, build upon this work non-commercially, and license their derivative works on different terms, provided the original work is properly cited, appropriate credit is given, any changes made indicated, and the use is non-commercial. See: http://creativecommons.org/licenses/by-nc/4.0/.

C Author(s) (or their employer(s)) 2019. Re-use permitted under CC BY-NC. No commercial re-use. See rights and permissions. Published by BMJ.

BMJ Open Qual 2019;8:e000042corr1. doi:10.1136/bmjoq-2017-000042corr1

(D) Check for updates 